\title{
A Crise Argentina de 1890: Dívida e Instabilidade Externa"
}

\section{The Argentine Crisis of 1890: Instability and Foreign Debt}

Maria Heloisa Lenz ${ }^{* *}$

Resumo: A economia argentina experimentou um período de intenso crescimento no século XIX, a Belle Époque, cujas características foram sua agregação ao mercado externo, através de produtos, capital e imigração. O financiamento e as atividades bancárias também foram características deste período. Os bancos estrangeiros no país influenciaram o comportamento do sistema, principalmente as ações Baring Brothers e a adoção do padrão ouro. A crise Baring Brother foi desencadeada pela falta de confiança dos papéis argentinos pelos investidores ingleses devido às dificuldades do governo argentino e também pela dívida externa. Este artigo consiste em dois segmentos. O primeiro tratará das características do sistema bancário argentino e a crise do Baring Brothers. O segundo descreve a evolução da dívida e dos acordos externos: o Comitê Rothschild, de 1891; o Acordo Romero, de 1893 e o Acordo Terry Deal, de 1896.

Palavras-chave: Argentina. Dívida externa. Crise monetária.

Abstract: The Argentinean economy experienced an extraordinary economic growth in the $19^{\text {th }}$ century, when its characteristic was its aggregation to the international market, the Belle Époque period, by products, labor and capital. The financial and banking activities themselves were also characteristics of that period. The private banks in the country very much influenced the system's behavior, the activities of the Baring Brothers and the adoption of the gold standard. The Baring Brothers crisis of 1890, was unleashed by the lack of trust in the Argentinean bonds and shares on the part of the English investors, and by the size of the foreign debt. This paper consists of two segments. The first segment analyzes the beginning of banking activities in the country and the

Trabalho apresentado no XI Encontro Nacional de Economia Política da Sociedade de Economia Política (SEP), em Vitória, Espírito Santo, em junho de 2006.

** Professora-associada I do Departamento de Economia e do Programa de Pós-Graduação em Economia da UFRGS. E-mail: heloisa.lenz@ufrgs.br 
Baring Brothers crisis. The second describes the evolution of foreign debt and deals: the Rothschild Committee of 1891, the Romero Deal of 1893 and the Terry Deal of 1896.

Keywords: Argentina. Foreign debt. Monetary crisis.

JEL Classification: N16; N26; F34.

\section{1 lntrodução}

No final de 2001, o mundo foi surpreendido com a notícia da ocorrência de uma grave crise econômica e social e até de constitucionalidade na Argentina. O que mais surpreendeu o mundo foi o fato de que um país como a Argentina, que experimentou um período de intenso crescimento no final do século XIX, a Belle Époque, e que despontava como uma das nações com maiores taxas de crescimento econômico no mundo, a ponto de ser comparada a países como Estados Unidos e Canadá, pudesse agora enfrentar essa enormidade de problemas econômicos, sociais e políticos. Mas esta situação de crise não é nova e já tinha sido experimentada pelo país no final do século XIX, mais precisamente nos anos 1890, quando ficou comprovado que aquele período de crescimento e riqueza não tinha sido sustentado, levando a Argentina, já naquela época, a uma crise de caráter financeiro, com grandes repercussões externas. O objetivo deste artigo, assim, é a caracterização desse momento histórico, na tentativa de identificar os principais aspectos da crise de 1890. Acredita-se que as características dessa crise, sua relação com a dívida externa e as fases das negociações externas levadas a efeito merecem ser estudadas como forma de esclarecer a crise do início do século XXI, pelas semelhanças que ambos os episódios guardam entre si. O trabalho está estruturado em duas partes principais. A primeira tratará das características da evolução do sistema bancário e das relações externas que desembocaram na grande crise do final do século XIX. Na segunda parte, será examinada a questão do endividamento externo e os Acordos Externos realizados para a solução do mesmo. As considerações finais, além de sumarizar as características do período, também procurarão estabelecer alguns traços de similaridades entre as duas crises e as perspectivas do país. 


\section{A Evolução do Sistema Bancário Argentino e a Crise dos Anos 90 no Final do Século XIX}

O período de extraordinário crescimento experimentado pela economia argentina no final do século XIX, a Belle Epoque, que teve como a característica mais marcante a sua integração ao mercado internacional, foi de tal intensidade que a Argentina despontou como a principal protagonista dos processos de crescimento que marcaram o continente latino-americano nos séculos XIX e XX, valendo-lhe inclusive a comparação com países como os Estados Unidos e o Canadá. Dentre as inúmeras características do período, as mais marcantes foram a troca de posição relativa em termos de crescimento econômico que a Argentina e os demais países latino-americanos experimentaram a partir do último quartel do século XIX, a expressiva incorporação de terras para o cultivo, o crescimento das exportações, o enorme contingente de capital e mão de obra estrangeira que ingressou no país e, sem dúvida, as crises bancárias e da dívida externa que levaram o país à insolvência.

As crises bancárias e externas foram resultadas de várias decisões de políticas visando a este modelo de crescimento aberto, montado no tripé externo: capital, mão de obra e exportações. Assim, a característica mais marcante deste período foi a sua integração externa, mais precisamente com a Grã-Bretanha. Essas relações envolveram desde tratados entre os dois países como a abertura externa via exportações e o afluxo de capital com grande preponderância inglesa. ${ }^{1}$ Deste modo, a construção de um sistema bancário compatível com as exigências externas foi um dos seus requisitos principais.

Os anos 1880, início do período de crescimento, marcaram o início da constituição do sistema bancário argentino, com destaque para a consolidação do Banco de la Provincia de Buenos Aires como a instituição mais importante do país. A sua clientela era prioritariamente composta pelos grandes proprietários de terra e por importantes grupos de ricos imigrantes, além de uma grande participação de cidadãos ingleses. O Banco estabeleceu fortes relações com o mercado financeiro e também desempenhou as funções de um Banco Central. Essas sobrecargas de funções, contudo, comprometeram a sua saúde financeira, principalmente por pertencer à província mais importante do país, fato que sempre comprometeu a sua trajetória devido à função expressa de ter de providenciar recursos financeiros para o governo provincial. O Banco Nacional, criado em 1872, para funcionar como uma forte

1 Para mais informações sobre as relações entre a Argentina e a Inglaterra e principalmente sobre a inserção da Argentina no contexto internacional, ver Lenz (2008). 
instituição nacional, também não conseguiu exercer as suas funções de fomento do crescimento, já iniciando suas atividades de forma enfraquecida, novamente pela participação do Estado. Outros fatores destabilizantes foram os problemas decorrentes da implementação do padrão ouro e dos sistemas cambiais. Essas características das primeiras instituições bancárias influenciaram fortemente todo o comportamento posterior da economia argentina.

Uma das grandes dificuldades do período era a falta de uma moeda nacional. A primeira tentativa de sua criação, em 1881, foi abortada por problemas especulativos e depreciações monetárias, e só em 1883 foi estabelecido o peso nacional ouro. Mas a sua duração foi só até 1885 , quando passaram a existir dois sistemas monetários: o papel-moeda nacional, usado internamente, e o ouro, ou a libra esterlina, utilizados nas transações internacionais. Outro experimento importante do período foi a lei dos Bancos Nacionales Garantidos, em 1887, a qual estabelecia que qualquer banco pudesse emitir, sob a condição de realizar um depósito em ouro correspondente no Tesouro Nacional. Na verdade, a lei estabeleceu as moedas lastreadas em dívida federal, sendo que o objetivo principal era a criação de uma moeda-papel uniforme para todo o país. Houve adesão crescente ao sistema por parte da maioria das províncias, mesmo as mais pobres. Essas atribuições, aliadas às pressões políticas, geraram uma extraordinária expansão monetária, levando a sérios problemas especulativos.

Duas circunstâncias tiveram influências negativas na evolução das instituições financeiras argentinas até 1890. A primeira foi que a atividade bancária supunha a existência, em um país em rápida expansão econômica, de uma quase ilimitada demanda por dinheiro. A outra vinculou-se à influência do Estado no negócio bancário de emissão, através dos Bancos Garantidos. Esses bancos foram utilizados principalmente para dispor de recursos para o setor público, mas também para a criação de dinheiro. Quando esta foi maior que sua demanda, produziu uma forte inflação e, como consequência, o entesouramento e a saída da poupança dos circuitos internacionais, o que atrasou a intermediação financeira.

Também foi importante a presença e o comportamento dos bancos privados estrangeiros no país, que influenciaram muito o comportamento do sistema, desde as atividades do poderoso Banco de Londres, ${ }^{2}$

2 A eles agregaram-se outros bancos estrangeiros, que não tiveram tanta importância. Destaca-se o Banco Mauá, com uma casa em Rosário, e, mais adiante, o Banco Mercantil, de capitais ingleses, que quebrou na crise de 1876. O Banco de Paris e o dos Países Baixos tiveram participação ativa no negócio ferroviário, promovendo a construção das estradas de ferro francesa em Santa Fé e em Buenos Aires. Também estabeleceram-se as firmas Stern Brothers 
com suas operações ligadas ao comércio externo, até as problemáticas e turbulentas ações da Casa Baring Brothers. Esta instituição estava ligada à Argentina desde o início como principal agente fornecedor de empréstimos, primeiro da Província de Buenos Aires e depois do país, através do levantamento de fundos no mercado financeiro de Londres.

Dada sua importância, o Baring foi responsabilizado pela febre especulativa dos anos 1880 e pelas condutas irresponsáveis dos governos que culminaram na crise de 1890 , razão pela qual é importante examinar a forma do Baring operar na Argentina nos anos 1870 e 1880. Foi especialmente notável sua participação na constituição e na negociação dos títulos da Sociedad de las Aguas Corrientes y Drenaje de Buenos Aires, uma grande empresa privada de utilidade pública, cujo fracasso contribuiu para a crise em 1890.

O Baring abandonou as suas tradicionais funções bancárias e políticas ao assumir a promoção e participar da criação da Sociedad de las Aguas Corrientes y Drenaje de Buenos Aires, para obter do Governo argentino a concessão das obras de drenagem e provisão de águas. Segundo Cortés Conde (1997, p. 138) "A concessão foi comprada por 21 milhões de pesos ouro, pagáveis em três cotas anuais, e, em troca disso, e da construção das obras, obteriam 10 milhões de libras em ações e debêntures da Compañia de Aguas Corrientes, que seriam vendidas ao público". Se tudo corresse bem, dentro do orçamento previsto, a venda das ações ao público geraria um lucro fantástico, mas, caso contrário, a empresa poderia constituir-se em um enorme desastre, pois o negócio era de alto risco. De acordo com as vendas dos primeiros lances de ações, que não foram bem recebidas pelo público, as perspectivas para as próximas também não eram as melhores. (CORTÉS CONDE, 1997, p. 138). Além disso, nessa época, o Baring também estava envolvido nas colocações de títulos de outras empresas, como da Ferrocarril Oeste.

Em 1889, os trabalhos da Companhia estavam atrasados e as obras exigiam somas muito maiores do que as colocadas no orçamento inicial. Dessa maneira: "Havia escassez de materiais e má administração, enquanto os consumidores resistiam a pagar em ouro pelo consumo de água, querendo fazê-lo em depreciados pesos papel" (CORTÉS CONDE, 1997, p. 139). Em outubro de 1890, os consumidores deviam à Companhia mais de 1.65 milhão de pesos ouro. Ao mesmo tempo, essa teria de pagar juros por suas debêntures e parte do preço de compra do Governo. Dos dois milhões de libras de ações, só 150.000 libras estiveram realmente disponíveis para o público, sendo que a maior parte

e L. Cohen, embora especializassem-se principalmente como o Baring na colocação da dívida pública nacional, provincial ou municipal (CORTÉS CONDE, 1997). 
ficou de responsabilidade financeira do Baring. Em artigo de novembro de 1890, a revista The Economist acusou o Baring de práticas enganosas e inescrupulosas para a venda dos títulos, afirmando que os recursos de mercado empregados em atrair investidores foram deliberadamente calculados para enganar (The Economist, 1890 apud CORTÉS CONDE, 1997, p. 139).

A bolha especulativa estourou nos anos noventa. A velocidade monetária diminuiu apreciavelmente, pois o público começou a entesourar. Os bancos, apavorados, negavam a concessão do crédito sem se importar com a solvência dos solicitantes. Em abril de 1890, o prêmio do ouro chegou a 166\% (ALVAREZ apud RAMOS, 1970). De 1889 a 1890, os depósitos do Banco Nacional encolheram de 1,084 milhão de moeda nacional para 614 milhões e os do Banco de la Provincia de Buenos Aires de 138 milhões moeda nacional para 68 milhões. (ARGENTINA, 1941).

Teve início, na Argentina, então, uma oposição política que se concentrou nos aspectos morais e legais, sobretudo nos problemas monetários e creditícios do governo nacional. Houve acusações a diretores de vários bancos de terem transgredido as leis emitindo grande quantidade de notas, além de favorecer seus amigos do governo com créditos e finanças por grandes somas.

O presidente Juárez Celman, por acreditar que toda a raiz do problema residia na especulação, tomou uma medida ingênua e nociva: proibiu a compra e venda do ouro. Essa ação, além de inócua, valeu-lhe uma torrente de críticas e a culpa pela ocorrência de uma nova onda de entesouramento e do aparecimento do mercado negro do ouro.

As primeiras medidas de Carlos Pellegrini, que tomou posse em 6 de agosto de 1890, foram drásticas para a economia e as finanças: a paralisação das obras públicas, a demissão de empregados supérfluos e a devolução de terras públicas de que o governo anterior tinha se apropriado sem autoridade. Na área monetária e bancária, as medidas mais importantes foram a autorização do aumento de capital para o Banco Nacional e a realização de novas emissões. Com as novas emissões, a circulação em novembro de 1890, atingiu o valor de $251.628 .645 \mathrm{~m} \$ \mathrm{n}$, todo ele de responsabilidade do Estado. Ao mesmo tempo, a população iniciou uma corrida bancária com a retirada de seus depósitos do Banco Nacional e do Banco de la Provincia de Buenos Aires, entesourando quase todo o dinheiro e depositando pequenas quantidades nos bancos privados. 
A crise iniciou em novembro de 1890, quando Londres não permitiu o adiamento do pagamento da dívida ${ }^{3}$ nem a continuidade da transferência trimestral de fundos para a Argentina. Na verdade, para o autor Ferns (1979), a crise bancária de 1890-95 resultou no questionamento da relação financeira entre o Governo argentino e os agentes financeiros da City de Londres.

A casa Baring havia recebido títulos do governo argentino por um valor nominal de aproximadamente 25 milhões de dólares, mas não podia colocá-los à venda, pois havia desaparecido a confiança na capacidade de pagamento do governo argentino (FERNS, 1979, p. 130).

A crise bancária argentina repercutiu fortemente nos meios financeiros londrinos e, tanto pelo temor das perdas dos banqueiros ingleses como pelo medo de que ela também alcançasse a Inglaterra, havia a expectativa da intervenção do Governo inglês. Entretanto, contrariando o esperado, o Governo da Inglaterra optou por uma política de não intervenção, nada fazendo para resolver a crise, exceto promover assistência ao Banco da Inglaterra, caso ele encontrasse dificuldades para mobilizar recursos da comunidade financeira para enfrentar a situação. ${ }^{4} \mathrm{O}$ episódio é, inclusive, considerado o mais enfático exemplo da política de não intervenção, como pode ser visto pelas declarações de algumas das principais autoridades, mostrando a determinação de uma parte do Governo inglês de não se envolver politicamente na Argentina durante a crise do Baring nos anos 1890.

Em 1890, muitas empresas novas quebraram e houve o anúncio da suspensão do pagamento dos dividendos trimestrais. Para resolver a questão da dívida externa, o Governo decidiu subscrever novo empréstimo com o Baring, a fim de evitar novos impostos e uma alta do ouro. Em meio a novas negociações, o Baring decidiu pela liquidação "[...] a menos que o Governo argentino a evitasse, pagando suas dívidas pendentes e eximindo-o da obrigação de pagar 1.400.000 libras esterlinas, terceira cota do empréstimo de Aguas Corrientes y Obras Sanitarias de

3 É importante salientar que foi, sem dúvida, a grande prosperidade do período anterior que, apoiada na abundância de empréstimos externos, resultou até o final da década de 1890 em uma dívida externa de 300 milhões de peso ouro. Houve também o aumento insólito da dívida pública argentina, que cresceu de 10 milhões de libras em 1874 para mais de 59 milhões naquele ano (CORTÉS CONDE, 1997, p. 159).

4 Segundo Eichengreen (2000), o Banco da Inglaterra tomou um empréstimo de três milhões de libras em ouro do Banco da França e obteve a promessa de 1,5 milhão de libras de ouro da Rússia. Com o estabelecimento de seu nível de reservas em ouro, o Banco da Inglaterra pode prover liquidez ao mercado londrino e, com a ajuda de outros bancos de Londres, contribuir para a formação de um fundo de garantia para o Baring Brothers, sem prejudicar as reservas necessárias para honrar seu compromisso de converter libras esterlinas em ouro. Os investidores foram tranquilizados e a crise foi superada. 
Buenos Aires" (WILLIANS apud FORD, 1975, p. 138). O Governo não pôde pagá-la, ou não tentou, e declarou a impossibilidade de cumprir com os pagamentos do serviço da dívida. Dessa maneira, Baring pediu solvência e ficou de posse de títulos argentinos, que só podiam ser negociados de imediato, à custa de grandes perdas. ${ }^{5}$ É evidente, para Ford (1975), que a crise aconteceu quando a pesada carga representada pelo pagamento do serviço da dívida recaiu sobre as exportações, únicas provedoras de moeda estrangeira. ${ }^{6}$ Tais circunstâncias determinaram que o Governo argentino não cumprisse suas obrigações, o que produziu o colapso do Baring. A situação agravou-se ainda mais com a queda dos preços mundiais dos produtos argentinos, em 1889.

Cortés Conde (1989, p. 212) resume a crise 1890 da seguinte forma: a depreciação do dinheiro, ou seu inverso, o aumento de preços havia resultado da emissão inconversível, da especulação com ouro, das condutas irresponsáveis do Governo e do pouco solidário comportamento dos prestamistas estrangeiros que investiram em ativos locais quando os rendimentos eram altos e se retiraram quando aparecia o primeiro sinal de insegurança.

Martí (1983) afirma que, para entender-se a crise, é necessário conhecer o mecanismo desses empréstimos. A maioria dos empréstimos que as empresas e os governos argentinos obtinha no exterior era em forma de juros fixos e, por conseguinte, implicava pagamento imediato de um serviço estipulado a ouro. De 1886 a 1890, a Argentina havia tomado emprestados aproximadamente 668 milhões de pesos ouro, e o seu passivo, em 1892, incluindo os empréstimos públicos e capitais estrangeiros em empresas privadas, alcançava 922545000 pesos ouro. Enquanto os fundos do exterior continuaram afluentes, não houve problemas no balanço de pagamento, ou seja, o País obtinha as divisas necessárias para fazer frente ao pagamento dos serviços da dívida externa e da manutenção do nível de consumo de artigos importados. "De este modo la crises sobrevino porque los fondos extranjeros disminuyeron antes que el valor de las exportaciones se hubiera expandido hasta un ponto que permitiera cubrir los servicios de la deuda y mantener un nivel de importaciones políticamente tolerable" (MARTÍ, 1983, p. 935). Por outro lado, os projetos financiados pelos empréstimos estrangeiros,

$5 \quad$ Cuccorese (1966) afirma que um bom exemplo das perdas dos investidores estrangeiros foi a dos que investiram em títulos das estradas de ferro, que cotizados na Bolsa de Londres sofreram uma perda de vinte milhões de libras esterlinas.

6 A descrição do desenvolvimento da crise para Ford (1975) é a seguinte: a) o ponto máximo da dívida da Argentina registrou-se em 1888; b) o volume máximo das importações aconteceu no curso de 1889; c) o máximo da construção das estradas de ferro se registrou em 1891; c) de 1893 em diante, aumentou o volume da produção e das exportações de cereais. 
principalmente a construção de estradas de ferro e o melhoramento das terras, promoveram uma produção crescente de bens exportados, mas devido a sua lenta maturação não conseguiram fazer com que o valor e o volume das exportações aumentassem no mesmo ritmo que o montante dos juros da dívida. Assim, segundo o mesmo autor, a crise sobreveio quando houve a interrupção dos empréstimos que eram respaldados em ouro, provocando uma depreciação monetária e ao mesmo tempo o crack do sistema bancário. Como decorrência, houve o início de quebra dos dois principais bancos argentinos e de alguns provinciais. ${ }^{7} \mathrm{~A}$ situação agravou-se ainda mais com a queda dos preços mundiais da produção argentina a partir de 1889 , com reflexos desfavoráveis sobre as exportações da Argentina. Avançando esta linha interpretativa, Rapoport (1988) defende que a crise de 1890 mostra os limites do modelo agroexportador, que teve por base o endividamento externo e um contínuo balanço favorável no comércio exterior. Qualquer alteração no setor externo ou na estrutura produtiva podia produzir rapidamente uma interrupção do processo.

A crise só começou a ser revertida quando, devido a novas negociações em Londres, o Banco da Inglaterra tomou a iniciativa de formar um fundo junto com outros bancos privados num total de 17 milhões de libras. A primeira consequência disso foi o Banco da Inglaterra ter continuado a aceitar os documentos do Baring. Em 1891, o Presidente Pellegrini assinalou que um sistema bancário fundado sobre a égide dos bancos oficiais tendia a enfraquecer, e que essa era uma opinião universalmente reconhecida. Esses defeitos poderiam entorpecer ou paralisar o sistema bancário, produzindo conflitos econômicos que comprometeriam os mais altos interesses públicos. Em relação ao Banco de la Provincia, ele expressou que esse estabelecimento, o qual servira de modelo e exemplo aos bancos fundados posteriormente pelo país e pelas províncias, tinha sofrido sérios problemas de descontrole monetário e que, por isso, o governo via a necessidade de reformular o sistema financeiro privatizando os bancos oficiais, pois existia a certeza de que o próprio Estado estava incapacitado de dirigi-lo.

Observa-se, entretanto, que embora os dados não sejam de todo precisos, a relação da emissão de notas bancárias não confirma a expansão monetária descontrolada, fenômeno que certamente deveria ser buscado na emissão das células dos bancos hipotecários cujas cifras,

7 Ford (1975, p. 119) afirma que essa crise não foi apenas uma crise bancária, mas sim uma crise de desenvolvimento, de esgotamento do modelo vigente extremamente dependente de recursos externos. Segundo ele, isso não foi entendido por muitos autores que privilegiaram em suas explicações fatores como a corrupção e a desonestidade na Argentina entre as principais causas dessa crise. 
altamente superiores, alcançaram os 400 milhões de pesos em títulos papel e 20 milhões de pesos em ouro (MARTÍ, 1983).

Em 1891, foi feita a última tentativa para salvar os dois grandes bancos oficiais: o Banco da Província de Buenos Aires e o Banco Nacional. O Governo nacional apelou para os bancos privados de Buenos Aires subscreverem um novo empréstimo interno, conhecido como Empréstimo Popular. Segundo Jones (1985, p. 73),

The power of the leading English bank, the London and River Plate Bank, is evidence in the price it exacted for participation in this futile exercise. A telegram despatched to London enunciated one element in the agreement. It read: 'If loan succesful promise has been given by Argentine President of Republic to cancel deposit tax.

Em abril de 1891, o Governo autorizou o Banco Nacional e o da Província a não pagarem os depósitos, garantiu as emissões dos Bancos Garantidos, que se converteram em obrigações da Nação, e recebeu os Fundos Públicos dos Bancos Garantidos que cederam sua emissão. O Tesouro do Governo Nacional ficou como credor dos bancos que, por sua vez, ficaram como credores de seus clientes pelos créditos que lhes outorgaram e o primeiro ficou como devedor de toda a emissão (CORTÉS CONDE, 1989, p. 240).

Apesar dos esforços, os dois bancos oficiais entraram em liquidação. O mesmo aconteceu com os Bancos Garantidos, assumindo o Governo nacional a emissão e estabelecendo uma moratória para todas as obrigações dos bancos. O Banco Nacional encerrou definitivamente as suas atividades, e o Banco de la Provincia permaneceu fechado por quinze anos.

Della Paolera (1994) sintetiza a situação do período da seguinte forma:

En suma, a mediados de 1891 el conjunto de medidas adoptadas había desmantelado los frentes fiscal y monetario: se había llevado a cabo una reforma tributaria, un ajuste draconiano en el sistema bancario con la liquidación del Banco Nacional y del Banco de la Provincia de Buenos Aires, el establecimiento de un órgano independiente para controlar la base monetaria y la renegociación de la deuda exterior (DELLA PAOLERA, 1994, p. 573).

Em outubro de 1891, no pico da crise, foi criado o Banco de la Nación, uma instituição semipública, com um capital de cinquenta milhões de pesos e cujas ações foram oferecidas para subscrição pública. Enquanto continuaram as operações do Banco Nacional, não lhe foi dada a faculdade de emitir cédulas. Ele só podia emprestar ao Governo 
nacional e, mesmo assim, somas que não fossem superiores a $20 \%$ de seu capital. O banco estava autorizado a fazer operações de redesconto das carteiras de outros bancos de até $\$ 500$ mil. Um decreto de 1892 - revogado em 1895 - obrigava-o a manter um encaixe de 75\% dos depósitos. Segundo Della Paolera (1994), em virtude de os investidores não terem se interessado por suas ações, o Governo respaldou o capital, o que o converteu, de fato, em uma instituição estatal.

As operações do Banco de la Nación apresentaram uma lenta evolução nos primeiros anos em função da desconfiança do público nas entidades oficiais. Em 1894, ele assumiu toda a circulação fiduciária, trocando as cédulas antigas por aproximadamente 300 milhões de novas. No decorrer do tempo e graças às suas sucursais que lhe davam um controle quase exclusivo dos negócios do Interior, suas operações tiveram um volume crescente e no começo do novo século já se firmara como a instituição financeira mais importante do país.

Duas foram as consequências da crise para o sistema financeiro. Os bancos já não se dedicariam principalmente à emissão dali em diante. Também desapareceram as cédulas dos bancos, e o papel-moeda do Governo ficou como único instrumento oficial. De acordo com Cortés Conde (1997), os bancos ocupar-se-iam, em troca, de operações comerciais de crédito. Ao mesmo tempo, os bancos privados adquiriram uma dimensão maior. Seus depósitos, minúsculos em relação aos dos bancos oficiais, aumentaram cada vez mais em volume e, em conjunto, superaram os bancos estatais na metade da primeira década do século XX. Os bancos privados, tais como o de Londres, o Espanhol, o do Rio da Prata, o da Itália, o Francês, dentre outros, aumentaram suas operações.

Os bancos argentinos, a partir de então, passaram a ser principalmente comerciais, e o conceito de atividade bancária já se aproximava mais da forma de intermediação financeira do que da criação de dinheiro. Também foram criados novos bancos locais, como o Banco Tornquist, mais ligado às empresas industriais, ainda que os bancos de negócios com participação direta em atividades industriais nunca foram realmente importantes na Argentina nesta época. De acordo com Gondra (1943), um ato profundamente significativo foi a considerável importância das atividades que se concentrava na instituição bancária de Ernesto Tornquist, que tinha começado em 1866 como dependente do comércio. Em julho de 1908, em pouco menos de meio século, suas inversões totais totalizavam 250 milhões de pesos. A principal e mais importante ocupação de Tornquist era de negociação de empréstimos públicos, além de inúmeras operações comerciais, agrícolas, de gado e industriais. Estas operações abarcavam a Compañia Azucarera Tucumana Refinaría Argentina, Talleres Metalúrgicos San Martín, Cotécnica, 
Ferrum Sociedad Anónima de Metales, Compañia de Productos Conen, entre outros.

Depois de um período de forte contração monetária como decorrência da crise, em que a queda do peso que chegou a 400\%, o Governo enfrentou uma fundamental reforma monetária, a Reforma Monetária de 1899. De acordo com Rapoport (1988), houve o início de um processo de apreciação do peso, e isso vinha contra o interesse dos comerciantes e produtores de exportação, que tinham seus custos em papel e vendiam seus produtos em ouro, e, por isso, começou uma forte campanha para deter a valorização, assegurando sua conversibilidade em relação ao ouro.

A primeira ação da Reforma de 1899 foi a criação da Caja de Conversión, cuja função era emitir ou retirar cédulas de circulação. Ramos (1970) afirma que o começo real da existência da Caja foi em 1899, ou de fato em 1902, quando passou a entregar ouro em troca de notas, mas que depois ela adquiriu tal importância e que sua vida se estendeu até $1935 .^{8}$

A Caja de Conversión, que foi criada seguindo o modelo do Issue Department del Banco de Inglaterra, na sua ação de conversão não incluiu os 300 milhões de moeda nacional das emissões anteriores, que ficaram a descoberto, assim como também os 14 milhões de libras no tempo da conversão britânica de 1844, sendo dito que isso seria realizado em uma data posterior. Como eles equivaleriam a aproximadamente 130 milhões de peso ouro, o esforço fiscal requerido seria de grandes proporções. Assim, em 1899, depois de um lapso de quase 20 anos, a Argentina retomou o padrão ouro. Esse passo foi tomado pelo Governo pela pressão dos exportadores, mas também foi para assegurar um novo compromisso com a estabilidade.

Evidentemente, o sistema da Caja assemelhava-se a um simples modelo de padrão ouro em que os movimentos internacionais de ouro afetavam automaticamente a oferta de dinheiro, com a diferença de que o ouro, que não se constituía no circulante interno, era convertido em papel moeda à taxa fixada por lei. Na prática esse modelo estava sujeito às restrições de que nem todo o ouro importado se converteria em papel moeda - podia engrossar o entesouramento dos particulares - e que as exportações de ouro podiam provir dos entesouramentos privados ou das reservas bancárias (FORD, 1966, p. 166). Para Regalsky (1999), as faculdades de emissão foram definitivamente desligadas dos estabeleci-

$8 \quad$ Na opinião de Fuentes (1988, p. 450), a lei de Conversão de 1899 só foi possível pelo fato de a economia argentina ter atravessado um período de balanço de pagamentos favorável. Para Ford (1966), a lei de Conversão de 1899 inaugurou um grande período de inflação autônoma, insignificante, que coincidiu com circunstâncias externas favoráveis, e com um crescimento econômico vigoroso. 
mentos bancários e transferidas a um organismo ad hoc como a Caja de Conversión, que deveria limitar-se a não agregar mais meio circulante.

A Reforma estipulava que todo indivíduo que levasse à Caja de Conversión o correspondente a 44 centavos de ouro receberia papelmoeda no valor de um peso moeda nacional e que poderia voltar a ser convertido em ouro a essa paridade, ou seja, ao câmbio de 2,2727 pesos moneda nacional por peso de ouro. Isso originava a conversibilidade do peso papel, a volta a um sistema de câmbio fixo que havia sido abandonado em 1885. Também seria constituída uma reserva metálica, chamada fondo de conversión, formado pelas reservas metálicas dos bancos Nacionais Garantidos, a soma do que os Bancos Nacionales Garantidos ainda deviam ao Governo e por todo o superávit que o governo pudesse ter. O melhoramento gradual das condições econômicas do país, ao cessarem as agitações políticas do período crítico 1890-1893, trouxe por consequência o saneamento da circulação fiduciária.

No início do século XX, o Estado argentino outorgava primeiríssima prioridade às finanças sólidas, o nível da oferta monetária e a manutenção de um tipo de câmbio fixo baseado no padrão ouro. A segunda prioridade foi a compensação dos efeitos dos movimentos do ouro na economia, e em último a regulação da atividade econômica mediante a política monetária. Essas preocupações foram dominantes até a Grande Depressão, e também foram consequências da crise financeira de 1890, que levou ao colapso dos bancos oficiais, ao aumento da dívida externa da nação, das províncias e das municipalidades e, em 1891, a queda do peso pela metade do valor que tinha em 1889. A reconstrução das instituições financeiras do país levou vários anos, e a capacidade do governo de controlar a oferta de dinheiro se viu obstaculizada por dois fatos: a) a dispersão das autoridades em quatro organismos distintos; b) a propriedade estrangeira dos bancos, os quais não aderiram ao sistema bancário nacional.

A estrutura bancária nos fins do início do século XX foi resultado das dificuldades experimentadas na década de 1890. Inicialmente constituído como uma empresa mista, o Banco da la Nación converteu-se em banco oficial em 1904. O capital do banco duplicou em 1907 e em 1912 assumiu funções na Câmara de Compensação. Os bancos estrangeiros, por sua vez, atendiam as necessidades creditícias que o Banco de la Nación não podia satisfazer com os bancos britânicos, preferindo limitar-se a empréstimos comercialmente seguros.

A associação dos bancos britânicos com a elite exportadora causava a impressão de uma preponderância estrangeira no setor bancário, reforçada pelo fato de que cada banco se especializava nas atividades que financiava. Por exemplo, o Anglo-Sudamericano monopolizou em 
certo momento o mercado de lã e carne da Patagônia e, por sua vez, os exportadores de grãos eram financiados por bancos londrinos. O Banco de la Nación, além de administrar crédito, tentou influir na atividade econômica, mediante a manutenção da conversibilidade, e mais tarde através da atividade de redesconto. Desde 1900 até o começo da Grande Depressão, concedeu-se prioridade, entre os diversos objetivos econômicos, à manutenção da conversibilidade com um tipo de câmbio fixo. Esse regia-se pela Ley de Conversión, de 1899, promulgada em um momento de alta da taxa do câmbio. O governo argentino teve êxito em seu propósito de deter o aumento do valor do peso mediante a adoção do padrão ouro, do estabelecimento de um coeficiente para o reembolso de papel moeda, que deveria realizar-se em espécie, da acumulação de capital de uma reserva metálica e da manutenção do coeficiente espécie/papel mediante um departamento da Caja de Conversión (Oficina del Control del Cambio) que atuava como reguladora da moeda em circulação, segundo a quantidade de ouro depositada.

Contudo a Caja de Conversión foi fechada em 1914, segundo Ford (1966), devido à retirada do capital dos investidores argentinos da Argentina, a baixa do valor da terra, a redução do comércio internacional, que diminuiu ainda mais as rendas públicas e o encerramento das fontes externas de crédito.

Em 1914 o pagamento em ouro foi prorrogado pelo tempo em que a Caja de Conversión permanecesse fechada, permitiu-se ao Banco de la Nación utilizar o fundo de compensações para operações de câmbio. Assim, a Caja funcionou, na prática, entre 1903 e 1914 e, novamente, entre 1927 e 1929, quando foi fechada definitivamente.

O governo argentino, a fim de manter sua posição creditícia no estrangeiro, seguiu exportando parte de seu ouro para atender os serviços da dívida externa, com a intenção de conter a depreciação do dinheiro. Expandiu-se também a oferta de dinheiro, mediante a autorização do depósito de ouro nas delegações argentinas no exterior, dando assim por terminado o funcionamento do padrão ouro na Argentina.

Como já foi visto, desde 1900 até o começo da Grande Depressão, o governo argentino concedeu prioridade à manutenção de um tipo de câmbio fixo sob a vigência do padrão ouro. A segunda foi a da compensação do impacto dos movimentos do ouro na economia. A fim de atingir esse objetivo, o Banco de la Nación solicitava empréstimos nos mercados internacionais e efetuava o redesconto. Durante o início de uma crise em 1914, o Banco pôde enfrentar os efeitos do ouro com as reservas.

Durante a Grande Depressão, os bancos tentaram recuperar seus empréstimos, porque uma queda de $50 \%$ nos preços agropecuários 
produziu uma diminuição do valor dos papéis comerciais para o redesconto. Em 1932, redigiu-se um projeto de lei para a criação do Banco Central, que acabou ocorrendo de fato em 1935. O primeiro diretor do Banco Central foi Raúl Prebisch, que havia criticado as práticas defeituosas dos bancos nacionais argentinos, acusando-os de terem publicado balanços falsos. Prebisch (1988) também acreditava que a lei apresentada pelo Congresso não era adequada às condições do país, e por isso apresentou algumas modificações ao projeto. A Argentina assim suspendeu o padrão ouro por trinta dias, em 20 de agosto de 1914, acreditando que o retorno à conversibilidade era iminente; depois uma e outra vez, por intervalos de 30 dias, até dezembro de 1927, quando finalmente restabeleceu-se o padrão ouro. Segundo Dosman (2001), depois de dois anos desastrosos, houve a volta da suspensão, e permaneceu assim até 1943. Em 29 anos, o sistema não havia funcionado "normalmente", em absoluto. Em mais de 3/4 de século, a conversibilidade só havia durado 23 anos.

\section{Endividamento Externo e os Acordos para a Superação da Dívida Externa}

A outra face da entrada maciça de capital na Argentina no final do século XIX foi o crescimento da dívida externa, que, com o correspondente aumento das taxas de juros e das amortizações, experimentou um aumento cada vez maior. A sua pesada carga trouxe grandes repercussões para o desempenho da economia argentina.

Mesmo os autores mais críticos da dependência argentina ao capital externo, concordam que não havia outra forma factível, nas condições da Argentina do século XIX, para reunir os grandes volumes de capital requeridos, como das empresas de estradas de ferro. Ao mesmo tempo, também era sabido pelo governo argentino que isso estava fora de seu alcance. Cortés Conde (1997) salienta que os governos argentinos, até a primeira metade do século XX, viveram a angústia permanente de que seus recursos não fossem suficientes para fazer frente a seus gastos e aos novos investimentos.

A solução para essa urgência de recursos foi a atração de entradas de capitais externos, que por sua vez trouxe outros efeitos: possibilitou o aumento dos gastos e uma expansão monetária que resultaria em crises. Dessa forma, com a chegada dos empréstimos externos, iniciava-se ao mesmo tempo a dívida externa púbica, com seus encargos e juros.

Até 1880, só existiram dois empréstimos externos, o da Casa Baring para financiar a guerra do Paraguai, e o de Obras Públicas de 1870. Am- 
bos tiveram consequências distintas. O empréstimo do Baring, contratado em 1865 para financiar a guerra com o Paraguai, teve suas negociações prolongadas, o que fez com que os fundos só entrassem no país em 1868. A Tesouraria argentina registrou a entrada de $2.9 \mathrm{M} \$ \mathrm{~F}$ nesse ano e $1.7 \mathrm{M} \$ \mathrm{~F}$ no seguinte. O financiamento inicial da guerra fez-se por meio de crédito do Banco de la Provincia, sendo que em 1865 ele recebeu a entrada de $3.5 \mathrm{M} \$ \mathrm{~F}$.

O empréstimo de Obras Públicas de 1870 foi obtido pela Província de Buenos Aires, que teve acesso mais cedo aos mercados internacionais de capital do que o estado nacional. Por sua vez, o governo federal, entusiasmado com a emissão da dívida provincial que havia sido realizado pela Casa Baring, aproveitou-se do clima de abundância financeira existente nos anos anteriores à guerra franco-prussiana e conseguiu empréstimos para construir os portos de Buenos Aires e de Rosário e para a construção das estradas de ferro, no final dos anos 1860. Ele foi responsabilizado pela ocorrência da crise dos anos 1873-1876.

Novos créditos externos foram sustados em 1876. O déficit do governo baixou substancialmente, produziram-se superávits e existiu uma fortíssima contração de depósitos. Somente depois do programa de estabilização, em princípios dos anos 1880, e a volta da conversibilidade 1883, iniciou-se uma nova época de ativa entrada de fundos do exterior.

Um exercício interessante é cotejar o total dos empréstimos externos e seus serviços com os diversos tipos das importações do país, assim como a extensão das estradas de ferro e os principais produtos de exportação argentinos, como podem ser vistos na Tabela 1.

Tabela 1 - Deuda Externa, Extensiones de las Vías Férreas y Exportaciones$1885-1890$

\begin{tabular}{|c|c|c|c|c|c|}
\hline & $\begin{array}{l}\text { (1) } \\
\text { Total de la deuda } \\
\text { externa (millones }\end{array}$ & $\begin{array}{l}\text { (2) } \\
\text { Longitud de las } \\
\text { vías completadas }\end{array}$ & $\begin{array}{c}\text { (3) } \\
\text { Trigo } \\
\text { exportado }\end{array}$ & $\begin{array}{c}\text { (4) } \\
\text { Maíz } \\
\text { exportado }\end{array}$ & $\begin{array}{c}\text { (5) } \\
\text { Lana } \\
\text { exportada }\end{array}$ \\
\hline & de pesos ouro) & (kilómetros) & \multicolumn{3}{|c|}{ (miles de toneladas) } \\
\hline 1886 & 68 & 1334 & 38 & 232 & 136 \\
\hline 1887 & 154 & 853 & 238 & 362 & 109 \\
\hline 1888 & 248 & 882 & 179 & 162 & 132 \\
\hline 1889 & 154 & 567 & 23 & 433 & 142 \\
\hline 1890 & 45 & 1294 & 328 & 707 & 118 \\
\hline 1891 & 8 & 3043 & 396 & 66 & 139 \\
\hline 1892 & - & 1207 & 470 & 466 & 155 \\
\hline 1893 & - & 170 & 1008 & 85 & 123 \\
\hline
\end{tabular}




\begin{tabular}{r|r|r|r|r|l}
\hline 1894 & - & 178 & 1608 & 55 & 162 \\
\hline 1895 & 17 & 86 & 1010 & 772 & 201 \\
\hline 1896 & 37 & 345 & 532 & 1571 & 188 \\
\hline 1897 & 38 & 294 & 102 & 375 & 206 \\
\hline 1898 & 46 & 696 & 645 & 717 & 221 \\
\hline 1899 & 25 & 962 & 1713 & 1116 & 237 \\
\hline 1900 & 26 & 150 & 1929 & 713 & 101 \\
\hline
\end{tabular}

Fonte: Ford (1975, p. 126).

Diferentemente da década anterior, em 1880, os serviços da dívida externa tinham de ser pagos imediatamente depois de contraída e ficava estipulado que a maior parte do montante total também deveria ser paga, o que constituía um peso adicional sobre a economia argentina. Os serviços da dívida externa continuaram a ser pagos normalmente após 1889, ainda que tenha havido poucos novos empréstimos no período. Ao mesmo tempo, o valor das exportações manteve-se praticamente estável entre 1889 e 1898, devido à lenta concretização dos planos de inversão, as condições climáticas e a repentina queda dos preços mundiais das exportações argentinas entre 1890 e 1896.

Assim, o decréscimo dos empréstimos externos entre 1889 e 1890, ao não ser compensado por um aumento imediato na produção de bens exportáveis, pois o incremento atribuído ao endividamento externo ocorreu apenas vários anos depois, levou a que os encargos do serviço da dívida externa pesassem mais sobre as receitas em divisas, então reduzidas. E, depois de 1893, quando os projetos de inversão começaram a dar frutos sob a forma de uma maior produção e exportação de cereais, os preços mundiais em queda neutralizaram o crescente volume das exportações.

Assim, os empréstimos estrangeiros aumentaram e, portanto, havia uma farta oferta de moeda estrangeira, como no próspero período de 1885-1889, a economia argentina pôde enfrentar, sem dificuldade, o pagamento dos serviços da dívida e, ao mesmo tempo, manter o aumento das importações. No entanto, quando os empréstimos cessaram, a situação mudou completamente e se instalou a crise.

Sem dúvida, o caso da Argentina ilustra como podem ser importantes os movimentos adversos nos termos de intercâmbio e, muito especialmente, a queda dos preços de exportação. Isso se deve ao aumento do peso real da dívida que ocorre se o juro e a amortização são em sua maior parte fixos e se os preços das exportações caem. Obviamente, tais movimentos não podem ser previstos claramente.

Assim, o intenso endividamento externo que acompanhou todos os momentos da vida econômica argentina, que alcançou o seu ponto 
máximo de 59 milhões de libras em 1890 quando eclodiu a crise dos anos 1890 , e a recusa do sistema financeiro internacional pelos títulos argentinos nesse mesmo ano levaram à necessidade do enfrentamento dessa situação, principalmente pelas repercussões na economia do país.

Do ponto de vista da Argentina, a crise foi resolvida por meio de um acordo entre os banqueiros e as autoridades argentinas. O primeiro estágio do acordo envolveu os banqueiros, emprestando dinheiro para capacitar o governo argentino a pagar a moratória dos juros e a cobrança de fundos perdidos. Essa política de pirâmide da dívida da Argentina foi considerada uma má política do ponto de vista argentino.

No segundo estágio, o governo argentino tomou a iniciativa: assegurou que as futuras negociações fossem abertas em Buenos Aires por um representante britânico que tivesse um real conhecimento das circunstâncias argentinas, o qual, no fim, conseguiu uma redução dos juros e uma supressão do pagamento dos fundos perdidos por um período de tempo que permitisse à economia crescer e, por esse meio, manter um controle independente do tamanho, da natureza e do propósito de seu débito externo.

As negociações entre as autoridades argentinas e os credores externos, que envolviam interesses de ambas as partes, foram repletas de lances com várias marchas e contramarchas. As negociações, na verdade, já iniciaram antes da crise do Baring, mas só adquiriram um caráter de urgência com a eclosão da mesma. No primeiro round de negociações, o Comitê do Banco da Inglaterra ou Comitê Rothschild, depois de examinar a situação de inadimplência da dívida do governo argentino, concluiu que a solução era continuar emprestando ao país. Os desacordos ocorreram em relação ao tipo de ajuda que seria dada, que variavam desde a proposta que contemplava a não concessão de empréstimo e a exigência de reformas, àquela sustentada pela Inglaterra de um empréstimo entre 12 e 15 milhões de libras.

Como bem observou Ferns (1979), a posição favorável inglesa estava muito direcionada para a solução tanto dos problemas dos investimentos em estradas de ferro, pelo efeito de fazer baixar os juros, como para ajudar o Baring, pelo fato de manter os títulos argentinos com uma sobrevida no mercado. As posições conflitantes levaram ao rompimento das negociações, com a saída dos demais integrantes europeus, sendo o acordo assinado apenas por Rothschild em 1891 e constituiu-se em um empréstimo de 15 milhões de libras. O fechamento dessas negociações conseguiu acalmar o mercado, e os títulos argentinos continuaram sendo aceitos nas transações. Novas negociações levaram a um novo programa de pagamentos em que o total do serviço e amortizações da 
dívida, elevada para 194 milhões de pesos ouro, seriam pagos integralmente até o ano de 1901.

Um novo acordo firmado em 1893, o Acordo Romero, obteve vários resultados, entre eles: o governo argentino concedia aos bancos o cancelamento dos compromissos da Compañia de Aguas y Obras de Salubridad, a redução dos juros dos títulos externos argentinos para aproximadamente $4 \%$, e a redução total do pagamento dos juros em torno de $30 \%$. Mas o mais importante foi a inclusão das dívidas das províncias, que não tinham sido incluídas no Acordo da Inglaterra, pois havia o entendimento de que isso significaria a externalização de uma dívida externa. Essas negociações para incluir os débitos externos das províncias foram concluídas em 1896 e geraram gestões paralelas, havendo sido denominadas Acordo Terry, em homenagem ao Ministro da Fazenda que comandou as negociações. A dívida externa argentina, no final da década de 1890, com a agregação das dívidas das províncias, 151 milhões de pesos ouro, alcançava o montante de 300 milhões de pesos ouro. A melhoria das condições da economia argentina, no início do século XX, junto com a aprovação da lei de 1905, que aprovou tanto a conversão como a redução dos juros, encerrou a etapa dos acordos e das questões relacionadas com a dívida externa, que acompanharam o período de crescimento da economia argentina.

Finalmente, é importante examinar os valores da dívida externa argentina após os acordos Rothschild, Romero e Terry. Em 1880, a dívida externa total alcançava 33 milhões de peso ouro e as exportações 54 milhões de peso ouro, pois os seus valores cotejados dão uma ideia da magnitude da dívida. Em 1892, depois do acordo com o Comitê do Banco da Inglaterra, ela alcançou 193.7 milhões de peso ouro e as exportações chegavam a 87 milhões de peso ouro. Em 1893, depois do Acordo Romero, a dívida passou para 220.6 milhões de peso ouro e as exportações 90 milhões de peso ouro. Em 1896, com o acordo Terry, agregaram-se 86 milhões de peso ouro do cancelamento das dívidas provinciais de 151 milhões de peso ouro. A quantidade total da dívida externa nacional superava, até fins da década de 1890, os 300 milhões de peso ouro, aumentando, assim, quase 10 vezes desde 1880 .

Em 1899, o regime da Caja de Conversión e a volta do padrão ouro levaram ao aumento das exportações e a um comportamento mais responsável do governo nos anos seguintes da crise, o que permitiu a criação de um clima de confiança na capacidade de pagamento do país. Também em 1897, o estado de contas da Argentina começou a mostrar balanços persistentes e crescentes favoráveis. Nestas circunstâncias, que se prolongaram até 1913, a economia argentina via diminuída a possi- 
bilidade de enfrentar novos problemas em nível internacional (FERNS, 1979, p. 651).

A Lei 4.600 de 1905 aprovou a operação de conversão dos títulos emitidos pela Lei 2.770 de 1891, conhecidos como Bonos Morgan, de $6 \%$ de juros e $1 \%$ de amortização por outros de $4.5 \%$ de juros e $0.5 \%$ de amortizações ou títulos da dívida interna de $5 \%$ de juros e $1 \%$ de amortização. Pela mesma lei também foi autorizado ao governo o cancelamento e/ou a retirada dos remanescentes títulos da dívida externa, emitidos por sucessivas leis, de 1882 a 1896, que seriam convertidos em títulos da dívida externa a $4 \%$ de juros e $0.5 \%$ de amortização. A sólida posição financeira do governo argentino, no pico do clima de confiança que se havia instaurado, permitiu a operação de conversão, que significava a redução das taxas de juro, e assim concluindo com os acordos que puseram ponto final no problema da dívida externa argentina dos anos 1880.

\section{Considerações Finais}

As indagações que nortearam a execução deste artigo se centraram na busca do entendimento das causas que levaram a Argentina a despontar como uma das economias mais promissoras no cenário mundial no final do século XIX e início do XX, denominado de Belle Époque, e depois a sofrer crises sem nunca mais retornar aos altos níveis de taxas de crescimento antes alcançados.

Tendo como base o período de intenso crescimento experimentado pela economia argentina no final do século XIX, buscou-se a caracterização da crise propriamente dita. O conceito de crise foi visto como o próprio reflexo das escolhas anteriores, pois essas já estabeleceram tanto o limite do crescimento como também a sua fragilidade; desta forma, a crise configurou-se como endógena e adquiriu um forte caráter financeiro. Todos esses acontecimentos desembocaram na crise do modelo de crescimento, configurado no crescimento da dívida externa e na necessidade dos acordos externos para superá-la.

Como foi visto, a solução encontrada foi a atração do investimento externo com a preponderância dos provenientes da Grã-Bretanha. Esses investimentos assumiram a forma de empréstimos governamentais e para a construção das estradas de ferro. O Estado jogou um papel relevante na atração desses investimentos, já que na sua maioria representavam empréstimos governamentais, responsabilizando o governo argentino pela entrada de capital e pelos juros dos empréstimos contraídos. Pela falta de instituições financeiras capazes de conseguir os fundos necessários para financiar o investimento em capital social fixo, novamente 
coube ao Estado argentino propiciar o ambiente favorável à chegada dos novos investimentos.

A crise de 1890 foi desencadeada primeiro pela falta de confiança dos títulos e papéis argentinos, por parte dos investidores ingleses, em função das dificuldades do governo argentino de cumprir as suas obrigações, e pelo tamanho da dívida externa. Em segundo lugar, pelo peso da dívida externa recair quase exclusivamente sobre as exportações, que estavam com seu desempenho comprometido pela queda dos preços mundiais de seus produtos.

O endividamento externo argentino alcançou 59 milhões de libras em 1890, e os problemas com os títulos argentinos nesse mesmo ano levaram a uma série de negociações externas: o Comitê do Banco da Inglaterra ou Comitê Rothschild, de 1891; o Acordo Romero, de 1893, e o Acordo Terry, em 1896.

A dívida externa argentina no final da década de 1890, com a agregação das dívidas das províncias - 151 milhões de pesos ouro -, alcançava o montante de 300 milhões de pesos ouro. A melhoria das condições da economia argentina, no início do século XX, junto com a aprovação da lei de 1905, que aprovou tanto a conversão como a redução dos juros, encerrou a etapa dos acordos e das questões relacionadas à dívida externa, que acompanharam o período de crescimento da economia argentina. Deste modo, esta crise foi muito marcante na história do país e sempre foi considerada um divisor de águas em relação ao período de intenso crescimento experimentado pelo país no século XIX.

Durante o século XX, o país foi marcado por uma série de acontecimentos e turbulências: não completou o seu processo industrial de substituição de importações, e enfrentou o período do peronismo, a ditadura dos anos setenta, o Plano Austral com o presidente Alfonsin e o processo de hiperinflação de 1989.

Nos anos 1990, houve a retomada da oferta de recursos externos, e a Argentina, como os demais países da América Latina, recebeu um grande afluxo de capitais externos na forma de aplicações financeiras, que se constitui em um processo de liberação e abertura externa, culminando com a adoção do regime de currency board, que significou a dolarização decretada por lei 1991. A rigidez do regime cambial de currency board levava a implicação de que a oferta monetária ficava atrelada aos resultados dos fluxos de comércio externo e de capitais. Este processo gerou, novamente, grandes problemas de endividamento externo com as dívidas em dólares, o mesmo acontecendo com as províncias.

A economia argentina, assim, vivenciou o término da Belle Époque a partir da crise externa, não importando a sobreviva ocorrida na década de 20, uma vez que haviam se esgotado as condições sobre as 
quais o modelo tinha sido alicerçado. O fato de outras economias de povoamento recentes, muito afetadas na I GM, terem não só superado os problemas decorrentes, mas, além disso, terem se tornado economias ricas e poderosas, como o Canadá e os Estados Unidos, exemplifica ainda melhor o caso argentino que entrou em crise pela falta de poupança doméstica capaz de substituir a dependência do país ao capital internacional.

Finalmente, cabe lembrar que tanto o fim e, principalmente, o resultado da Primeira Guerra Mundial, como a crise que abalou o sistema capitalista em 1929, afetaram profundamente os países da América Latina, e, portanto, a Argentina, influenciando suas opções de crescimento. Como marco da política internacional, o fim da Primeira Guerra Mundial, em 1918, assinalou o declínio da Grã-Bretanha como principal potência hegemônica no sistema ocidental marcando, concomitantemente, a ascensão dos Estados Unidos para esta posição. Os Estados Unidos saíram da I GM como a nação mais favorecida, passando da posição de potência regional para mundial. Uma decorrência natural dessa nova posição foi o aumento de sua influência nos países da América Latina, e consequentemente na Argentina, começando um movimento que se denominou de "expansão da influência do dólar na área tradicional da libra".

A Argentina, principal país exportador de produtos alimentícios, com seu desempenho sempre ligado ao aspecto externo - mão de obra, capital e mercado externo - teve de buscar novas alternativas.

$\mathrm{Na}$ década de 1920, quando as condições externas modificaram-se, pondo fim à entrada de imigrantes e de capitais estrangeiros no país, a Argentina ainda era uma sociedade mista e complexa, com regiões modernas coexistindo com outras superatrasadas, e já mostrando sinais de saturação em relação à sua capacidade de absorver recursos externos, embora com muita dificuldade de encontrar novos caminhos para substituir a economia primário-exportadora.

O processo de industrialização substitutivo de importações foi iniciado na Argentina a partir dos anos trinta do século XX, através de políticas de proteção do mercado interno ao mesmo tempo que a grande maioria dos países da América Latina. Esta nova trajetória do país foi novamente marcada por períodos de crescimento com auges e declínios.

Depois de a Argentina ter sido citada nos anos noventa, no final do século XX, como exemplo de sucesso em relação à estabilidade externa e do afluxo de capitais nos fóruns internacionais, ocorreu novamente o início de uma crise em três de dezembro de 2001. Esta crise, agora ocorrendo no século XXI, teve início novamente com a evasão de dólares, com a queda de reservas, com o governo decretando o corralito na 
imposição de saques e outras operações bancárias, culminando com a declaração de default da dívida externa pelas autoridades argentinas e principalmente o fim do regime de conversabilidade cambial no início de 2002.

A crise do início do século XXI guarda muito das características da crise dos anos 1890, mostrando que as lições do passado ou não foram apreendidas ou foram simplesmente ignoradas.

\section{Referências}

ARGENTINA. Banco de la Nación. El Banco de la Nación Argentina en su cincuentenario. Buenos Aires: Banco de la Nación,1941.

CORTÉS CONDE, R. Dinero, deuda y crisis: evolución fiscal y monetaria en la Argentina, 1862-1890. Buenos Aires: Sudamericana; Instituto Torcuato Di Tella, 1989.

. La economía argentina en el largo plazo (siglos XIX y XX). Buenos Aires: Sudamericana; Universidad de San Andrés, 1997.

CUCCORESE, H. J. Historia económica financiera argentina (1862-1930). Buenos Aires: El Ateneo, 1966.

DELLA PAOLERA, G. Experimentos monetarios y bancarios en Argentina: 1861-1930. Revista de Historia Econômica: nuevos enfoques en la historia económica de España y América Latina, Madrid, v. 12, n. 3, otoño 1994.

DÍAZ ALEJANDRO, C. F. Essays on the economic history of the Argentina Republic. New Haven: Yale University Press, 1970.

DOSMAN, E. Los mercados y el Estado en la evolución del "manifiesto" de Prebish. Revista de la Cepal, n. 75i, dic. 2001.

EICHENGREEN, B. A globalização do capital. São Paulo: Editora 34, 2000.

FERNS, H. S. Gran Bretaña y Argentina en el siglo XIX. Buenos Aires: Solar, 1979.

FORD, A. G. El patrón oro, 1880-1914: Inglaterra y Argentina. Buenos Aires: Instituto Di Tella, 1966.

. La Argentina y la crisis de Baring de 1890. In: ZAPIOLA, M. G. El régimen oligárquico: materiales para el estudio de la realidad argentina (hasta 1930). Buenos Aires: Amorrortu Editores, 1975.

FUENTES, D. D. Latin America during interwar period: the rise and fall of the gold standard in Argentina, Brazil, and Mexico. In: COATSWORTH, J. H.; TAYLOR, A. Latin America and the world economy since 1800. Cambridge: Harvard University, 1988. [Series on Latin American Studies].

GONDRA, L. R. Historia económica de la República Argentina. Buenos Aires: Sudamericana, 1943.

HALPERIN, D. Historia contemporánea de la América Latina. Madrid: Alianza Editorial, 1982. 
JONES, C. The fiscal motive for monetary and banking legislation. In: PLATT, D. T. Argentina, Australia and Canada: Studies in Comparative Development 1870-1965. London: Macmillan, 1985.

LENZ, M. H. As intensas e conflituosas relações econômicas e financeiras entre a GrãBretanha e a Argentina: do final do século XIX até a Primeira Guerra Mundial. Econômica. Niterói, v. 10, n. 1, p. 55-78, 2008.

. Crescimento econômico e crise na Argentina de 1870 a 1930: a Belle Époque. Porto Alegre: Editora da UFRGS, 2004.

. Crise e negociações externas na Argentina no final do século XIX: o início da insustentabilidade do modelo aberto. Economia e Sociedade. Campinas, v. 15, n. 2, p. 375-399, 2006.

LYNCH, J. Las repúblicas del Río de la Plata. In: BETHELL, L. América Latina independente. 1820-1870. v, 6. Barcelona: Crítico, 1991. [Historia de América Latina].

MARTÍ, G. M. Argentina: la crisis de 1890. Endeudamiento externo y crack financiero. El Trimestre Económico, v. 57, n. 4, p. 933-965, 1990.

PREBISCH, R. Historia monetaria argentina. Anotaciones sobre nuestro medio circulante. 1776-1885. In: RAPOPORT, M. (Compilador). Economía e historia: contribuciones a la historia económica argentina. Buenos Aires: Tesis, 1988.

QUINTERO RAMOS, D. Q. Historia monetaria y bancaria de Argentina (1500-1949). México: [s. n.], 1950.

RAPOPORT, M. et al. Historia económica, política y social de la Argentina (1880-2000). Buenos Aires: Macchi, 2000.

RAPOPORT, M. El modelo agroexportador argentino: 1880-1914. In: RAPOPORT, M. (Compilador). Economía e historia: contribuciones a la historia económica argentina. Buenos Aires: Tesis, 1988.

REGALSKY, A. Banca y capitalismo en Argentina: 1850-1930. Un ensayo crítico. In: Ciclos. Buenos Aires, n. 9, v. 18, 1999.

Recebido em: 19/01/2010.

Aceito em: 07/05/2010. 